\title{
The Classification of Rural Settlements in Gjirokastra Region
}

\author{
Assoc. Prof. Albina Sinani \\ Department of Geography, Faculty of Education and Social Sciences, "Eqrem Çabej" University \\ Gjirokaster 6001, Albania; "sinanialbina@yahoo.com
}

\section{Doi:10.5901/ajis.2016.v5n3s1p24}

\section{Abstract}

The network of residential areas in the region of Gjirokastra has changed depending of a complex factors. This has affected to the utilization rate of the region's rural territories. Considering the economic orientation of rural settlements by relief factor, we look that in settlements that lie in the landscape field, dominates this main branch of the economy: agriculture, livestock, processing of agricultural and livestock products and trade. In settlements that lie in low relief and high montane prevail livestock and orchards, while in the mountainous terrain of petty farming prevails (in villages of municipalities Picar, Cepo, Pogon and Frashër). To achieve this classification serves the real estate registry, which contains books of plots, with surfaces by categories (arable land, orchard, vineyards, forests, pastures, unproductive land). Until 1990, social-economic factor determining in order to limit the application of the regulatory policies of rural settlements. The old system aimed the limiting of the occupation of agricultural land and increasing population density in the rural area. After 1990 have not been implemented proper policies for the development of rural areas. Gjirokastra region rural areas have outstanding value to the organization as space and landscape, as well as the architecture and internal organization of housing and other buildings, infrastructure etc. Cohabitation over the Albanian population and Greek, especially in the rural area, there are approximate customs and traditions, communication and behavior, building style furnishing of flats, etc., creating an original model of the rural community, which can serve as gjeohapësire nucleus of a regional cross-border dimensions, where citizens of both countries (Albania and Greece) working for sustainable rural development.

Keywords: Cohabitation, rural settlements, agriculture, livestock, building style.

\section{Classification According to the Function}

\subsection{Agricultural function}

Agricultural function ${ }^{1}$ is implemented mainly in hilly and field terrain. Interest to deal with this issue is indicative of the dominance of the agricultural area on the surface of each village. Related to this indicator are remarkable Gjirokastra District, Communes (Lower Dropull: 70.5\%, Lunxhëri: 44.2\% and Upper Dropull: 42.4\%) and Buz Commune of Tepelena District, where agricultural land consist in $47.3 \%$ of the total.

In Gjirokastra District, agricultural function is dominant in the villages of Upper Dropull Commune, Lunxhëri (Valare, Nokovë Erind and Gjatë), Odrie (Hundëkuq and Labovë the Great), Lower Dropull (Bularat, Vodhine, Likomil, Bodrishtë, Zervat, Jergucat, Kakavie and Dritë, Libohovë Center (Bulo, Upper Labovë and Nepravishtë) Cepo (Çepunë, Palokastër, Mashkullorë and Kodër), Antigone (Arshi Lengo), where agricultural area occupies more than $40 \%$ of the total.

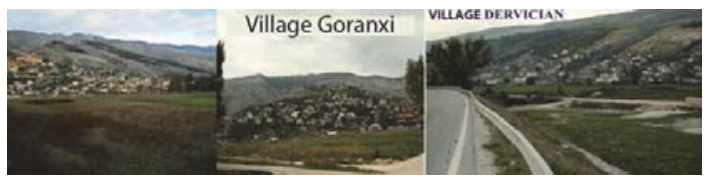

In Përmet District, agricultural function is dominant in the villages of the Commune Dëshnicë (Tolar, Bedyqas, Kuqar, Kodrishtë and Katundishtë), Piskovë Center (Kutal, Kosinë, Piskovë, Rapckë and Pacomit), Petran (Bodar, Gjinkar, Qilarisht, Petran and Badëlonjë) Çarçovë (Çarçovë and Draçovë), Suke (Gorica) and Këlcyrë village, where agricultural 
area occupies more than $40 \%$ of the total.

In Tepelenë District, agricultural function is dominant in the villages of the Commune Buz (Selckë, Glava, Golemaj and Shale), Qesarat (Anë Vjosë and Qesarat) Luftinjë (Tosk Martalloz, Ballaj and Upper Luftinjë), Krahës (Krahës, Zhulaj, Përparim and Lulëzim), Memaliaj Village (Cërrilë, Memaliaj Village and Mirina), Lopës (Sinanaj) and Center (Dragot), where agricultural area occupies more than $41 \%$ of the total.

\subsection{Livestock function}

Livestock function has settlements in high hilly and mountainous relief, with considerable pasture area (pastures, meadows and moat). In order to identify the villages and communes with livestock function is used indicator of pasture area.

For this indicator are remarkable communes of Gjirokastra District (Zagorie, Odrie, Antigone, Picar, Cepo and Lunxhëri), where pastures area occupy over than $40 \%$ of the total, as well as Tepelenë district (Tepelenë Center, Memaliaj Village and Kurvelesh), where pastoral areas occupy over $35 \%$ of the total.

In Gjirokastra District, livestock function is dominant in the villages of commune Zagorie (Lliar, Hoshtevë-Vithuq, Konckë, Ndëran, Doshnicë, Nivan and Upper Dropull Upper (Selo, Klishar, Kerr, Sotira, Llovinë, Krioner and Koshovicë), Picar (Golem and Kolonje), Odrie (Andon Poci and Lower Labovë), Poliçan (Selckë, Poliçan and Skore), Lunxhëria (Mingul, Karjan, Kakoz, Dhoksat, Këllëz and Gjatë), Antigone (Krina, Saraqinishtë and Asim Zeneli) Cepo (Prongji, Kardhiq, Humelicë and Mashkullorë) Libohovë Center ( Labovë e Vogël) Lower Dropull (Rada), where pastoral areas occupy over $41 \%$ of the total.

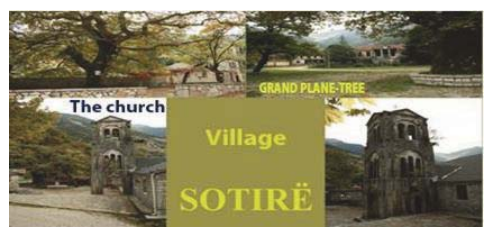

In Përmet District, livestock function is dominant in the villages of Këlcyrë Municipality, mainly in Mbrezhdan, where pastures occupy $36.5 \%$ of the total surface.

In Tepelenë District, livestock function is dominant in the villages the Commune Krahës (Xhaxhaj, Lekdush, Progonat and Nivica) Luftinjë (Izvor, Arrëz e Madhe, Vagalat and Zhapokikë), villages of Hormova, Veliqot, Lekël, Mezhgoran, Mamaj, Turan and Dukaj, villages Dames, Vasjar, Kashisht and Memaliaj Village of Commune Memaliaj Village, where pastoral areas occupy $45 \%$ of the total.

\subsection{Agro-Tourism function}

Agro-tourism function is evident mainly in settlements with remarkable agricultural traditions (where are implemented agricultural practices attractive to tourists), but also in places with tradition in the management of forests, water, etc.

To identify agricultural village with agro-tourism function serves indicator of occupation for forest area and water (rivers, streams and lakes) in the total surface of each village.

For this indicator are remarkable communes of Pogon, Petran, Çarçovë, Piskovë Centre, Dëshnicë, Suke, Kurvelesh, where forest and water areas occupy over $45 \%$ of the total.

In Gjirokastra District, function agro-tourism is dominant in villages of Commune Pogon (Sopik, Çatistër, Hllomo and Mavrojer) Zagorie (Topovë and Zhej), Picar (Shtëpëz and Picar) Upper Dropull (Pepel) and Odrie (Tërbuq) where forests and water surfaces occupying over $45 \%$ of the total.

In Përmet District, agro-tourism function is dominant in villages of the Commune Piskovë Centre (Alipostivan, Pagri, Grabovë-Argovë, Buhal, Pacomit and Rapckë), Petran (Lipe, Bënjë Novosel, Leusë, Kaludh, Badëlonjë, Leshicë and Gjinkar) Dëshnicë (Seniçan, Panarit, Riban, Varibop and Kuqar) Çarçovë (Biovizhdë, Vllaho-Psilloterë, Strëmbec, Kanikol, Zhepë, Draçovë and Pëllumbar) and Suke (Suke and Taroninë), where areas of forests and waters occupy over $43 \%$ of the total surface.

In Tepelenë District, agro-tourism function is dominant in villages of the Commune Kurvelesh (Gusmar and Rexhin), Buz (Lower Arrëz, Bader Kurtjez, Buz Kalemaj, Komar, Lower Selckë Xhafaj, Shala and Buz), Lopës (Lab Martalloz and Dorëz), Memaliaj Village (Bylysh and Kallëmb) Qesarat (Ahmanikaj, Koshtan, lliras and Qesarat), Tepelenë 
Center (Peshtan and Luzat), Luftinjë (Luadhaj, Maricaj, Upper Zhapokikë Dervishaj and Rrapaj) Krahës (Allkomemaj, Upper Krahës, Levan and Kalivaç), where forest and water areas occupy over $40 \%$ of the total surface.

\subsection{Agro-industrial function}

Agro-industrial function is dominant in settlements near cities, where are developed handicrafts and processing industry of agricultural products and livestock.

In Gjirokastra District, agro-industrial function is dominant in the villages of Commune Upper Dropull (Vrisera, Sotira, Bularat etc.), Lower Dropull (Dhuvjan, Sofratikë, Vanistër, Goranxi, Terihat etc.), Cepo (Kodër, Mashkullorë, Palokastër, Humelicë, Kardhiq etc.), Lunxhëri (Erind, Mingul, Valare etc.), Libohovë Centre (Bulo and Nepravishtë), Antigone (Arshi Lengo), Pogon (Poliçan) and Zagorie (Sheper).

In Përmet District, agro-industrial function is dominant in the villages of Këlcyrë Municipality (Këlcyrë Village) and Commune Petran (Leshicë, Petran, Bodar and Badëlonjë), Piskovë Center (Kosinë, Kutal and Piskovë), Suke (Zhepovë) Dëshnicë (Bedyqas, Kuqar and Tolar) and Çarçovë (Çarçovë and Pëllumbar).

In Tepelene District, agro-industrial function is dominant in the villages of Commune Lopës (Dhëmblan, Sinanaj and Matohasanaj) Krahës (Lulëzim and Krahës) Luftinjë (Dervishaj, Zhapokikë and Ballaj), Tepelenë Center (Dragot and Lekël), Buz (Buz and Xhafaj) Kurvelesh (Progonat) Memaliaj Village (Cërrilë, Memaliaj Village and Mirina) Qesarat (Anëvjosë and Qesarat).

\subsection{Settlements with administrative functions}

Those are settlements that have had and still have administrative functions (the localities, agricultural cooperatives and enterprises, villages and communes (municipalities).

\subsubsection{Before year 1945}

- Year $1934^{2}$

- Centre of Commune Rrëzë in Përmet District moved from village Draçovë to Petran, which was situated at the bank of Vjosa River, closer to Përmet and roadway;

- Centre of Commune Lab Martalloz in Tepelenë District moved from village Lab Martalloz to Sinanaj and Commune was called Sinanaj;

- Year $1938^{3}$ In Gjirokastër Prefecture was part of it:

- District of Centre, which consisted in Communes Gjirokastër Centre (with centre in Gjirokastër), Kardhiq (with centre in Prongji) and Zagorie (with centre in Konckë);

- District of Sub-Prefecture Libohovë, which consisted in Communes Libohovë Centre (with centre in Libohovë), Jergucat (with centre in Jergucat), Pogon (with centre in Poliçan);

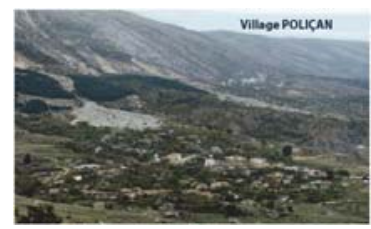

- District of Sub-Prefecture Përmet, which consisted in Communes Përmet Centre (with centre in Përmetin), Dëshnicë (with centre in Pavar), Këlcyrë (with centre in Këlcyrë), Petran (with centre in Petran) and Commune Frashër (with centre in Frashër);

- District of Sub-Prefecture Tepelenë, which consisted in Communes Tepelenë Centre (with centre in

2 Official Notebook, 19 May 1934.

${ }^{3}$ Official Notebook, Year of XVII, 17 June1938. 
Tepelenë), Krahës (with centre in Krahës), Rabie (with centre in Buz) dhe Sinanaj (with centre in Sinanaj);

- District of Sub-Prefecture Kurvelesh, which consisted in Communes Gusmar Centre (with centre in Gusmar) and Kuç (with centre in Kuç).

- Year $1940^{4}$.Village Labovë the Great it was turned to be the centre of new Communes of Labovë.

\subsubsection{Period 1945-1989}

- Year19495: In Gjirokastër District, Gjirokastra was the centre of locality Gjirokastër Centre, Jergucati - was the centre of locality Jergucat, Kardhiq - was the centre of locality Kardhiq, Libohova - was the centre of locality Libohovë, Nokova - was the centre of locality Lunxhëri, Poliçani - was the centre of locality Poliçan, Koncka was the centre of locality Zagorie.

In Përmet District, Pavari was the centre of locality Ballaban, Çarçova was the centre of locality Çarçovë, Frashëri - was the centre of locality Frashër, Këlcyra - was the centre of locality Këlcyrë and Petran - was the centre of locality Petran.

In Tepelenë District, Progonati was the center of locality Progonat, Buz the Great was the centre of locality Buz, Sinanaj was the centre of locality Sinanaj and Toç was the centre of locality Toç.

- Year19506

In Gjirokastër District, Sofratika was the centre of new locality Lower Dropull. On 10 October 1950, centre of locality Upper Dropull (former locality of Jergucat) moved to Vrisera, while centre of locality Lunxhëri moved to Erind.

- Year 19527: centre of locality Ballaban was transferred in Sukë of the same locality.

- Year 19548: in Tepelenë District, centre of new locality Krahës was turned Krahësi Nr. 1.

- Year 19559: in Gjirokastër District, centre of locality Kardhiq was Kardhiqi and the centre of locality ZagoriPogon - Poliçan. In Përmet district, centre of locality Ballaban was Sukë-Gorica, centre of locality Dangëlli Frashër, centre of locality Çarçovë - Çarçovë and centre of locality Këlcyrë - Këlcyrë. In Tepelenë District, centre of locality Buz was Buz, centre of locality Krahës - Krahës Nr. 1 and centre of locality Progonat Progonat.

- Year $1956^{10}$, in Gjirokastër District, centre of locality Pogon became Poliçan, while centre of locality Zagorie became Topova.

- Year 195811, in Gjirokastër District, Sofratika was centre of locality Lower Dropull, Vrisera was centre of locality Upper Dropull, Ura e Kardhiqit was centre of locality Kardhiq, Libohova was centre of locality Libohovë, Nokova was centre of locality Lunxhëri, Poliçan was centre of locality Pogon and Topova was centre of locality Zagorie. In Përmet District, Përmet was centre of locality Centre, Sukë-Gorica - centre of locality Ballaban, Çarçova - centre of locality Çarçovë, Frashër - centre of locality Frashër, Këlcyra - centre of locality Këlcyrë and Gjinkar-Petrani - centre of locality Petran. In Tepelenë District, Buzi i Madh was centre of locality Buz, Krahës Nr. 1 - centre of locality Krahës, Progonati - centre of locality Progonat, and Sinanaj - centre of locality Sinanaj

- Year 196512, through Decree Nr. 4069 dt. 15.11.1965, in Përmet District, centre of locality Ballaban moved to village Sukë.

- Year $1967^{13}$, Ura e Kardhiqit continued to be the centre of locality Kardhiq.

Centre of agricultural cooperatives has been village Asim Zeneli, while centre of agricultural enterprises villages Piskovë (in Përmet District), Valare, Arshi Lengo, Bulo and Andon Poçi (in Gjirokastra District).

\footnotetext{
${ }_{4}^{4}$ Official Notebook, 28 December 1940.

${ }^{5}$ Official Notebook nr 25, Year VI, 6 April 1949.

${ }^{6}$ Official Notebook, 30 March 1950.

7 Official Notebook nr 14, 15 September 1952.

8 Official Notebook nr 14, 25 September 1954.

${ }_{9}$ Official Notebook nr 18, 30 December 1955.

10 Official Notebook nr 9, 10 August 1956.

11 Official Notebook 2, 21 March 1958.

12 Official Notebook nr 10, 25 December 1965.

Official Notebook nr 6, 10 May 1967.
} 


\section{Spatial Organization in Function of the Dominant Activities}

Villages mentioned above, enjoyed the status of the administrative centre were also territorial centres of village systems locality, or agricultural enterprises- cooperative. These administrative centres were the promoters of the economic and social-cultural rural territories that had in their jurisdiction. In organizing the rural area primary role was the prevailing economic activity, which depended on relief and other natural conditions. Based on this, the administrative centres are classified into:

- Administrative centres in flat relief where is implemented agriculture, livestock where it was functioning agriculture, livestock breeding, etc. Such areas are: Jergucat, Sofratikë and Vrisera, in Gjirokastër; Këlcyrë and Sukë in Përmet District; Sinanaj, in Tepelenë District.

- Administrative centre in hilly relief, where it was functional fruit growing, agriculture and bee keeping: Prongji, Kardhiq, Nokovë, Erind, Upper Labovë, Topovë, Konckë and Poliçan, in Gjirokastër District; Draçovë, Petran, Ballaban, Çarçovë, Pavar, in Përmet District; Upper Buz, Rabie, Krahës, Toç, Lab Martalloz and Progonat, in Tepelenë District.

- Administrative centre in mountainous relief where it was functioning livestock breeding, beekeeping collecting of medical plants etc. Such village is that of Frashër in Përmet District.

\section{Classification of the Villages According to Ethnic Composition, Organizational Way and Architecture}

\subsection{The geographical distribution of ethnic groups and the classification of villages}

Historical, geopolitical, socio-cultural, economic and natural environment factors have affected the ethnic composition of the district of Gjirokastra. Data about this issue bring elements of cultural heritage (material and spiritual one) and coexistence of ethnic groups in this area before beginning the Ottoman period.

Geo spatial district is ethnically homogeneous, predominantly Albanian, but, as throughout history has experienced periods of non-Albanian population immigration, today there live representatives of ethnic Greeks, Vlachos and Roma cultural communities etc.

According to the census of $1989,86.6 \%$ of the Region population was Albanian and non-Albanian $13.4 \%$, meanwhile $97.76 \%$ of the non-Albanian population consisted of Greek national minority. Population of Yugoslav and Italian nationalities results respectively 18 to 4 . It has declined in time if we remember that in 1950 versus 1945 were repatriated in Gjirokastra district many Italians and Yugoslavs come during the war.

\section{- Greek Minority ${ }^{14}$}

The official policies of the Republic of Albania have supported the cultural, educational, spiritual, scientific and minority bilingual formation. Greek minority integration into society has positively affected the district rural development.

Historical records show that the language immigrations of the Greek population in Gjirokastra region occurred during the XIV and XVIII century, as farmers in Albanian feudal fields. Greek farmers first settled in the valley of the Drino, in communes of Lower and Upper Dropull and Pogon in about 41 villages. The arrival of this population led to the change of the ethnic structure of the southern region.

In the League of Nations declaration of 1921, is provided an overview on the geographical spread of the Greek minority in Gjirokastra region. Greek-speaking population preserve its compactness and was centred in the sub prefecture of the Centre, in 9 villages with 4838 inhabitants or 15.2\% of the population; in the sub prefecture of Libohovë in 28 villages with 13,573 inhabitants or $43 \%$ of the population and in the sub prefecture of Bazaar, in the villages and

\footnotetext{
14 International \& National Legislation for protection of national minorities in Gjirokastër Region:

-Declaration of Union of Nations, 02.10.1921,

- Universal Declaration of Human Rights (1948).

-National Convents for civil and political rights (1966).

-Constituency of Socialist Republic of Albania (1976), introduced de jure minorities, Paris Convent for a new Europe (1990).

-Constitution Dispositions of 1991, improve the status of minorities.

-Law of year 1993 "About the rights and principal freedoms of human beings",

-DCM Nr. 396, dt 22.08.1994 allows learning of native language even in the areas which are not inhabited from minority population.

-EU Convent - with the framework to protect national minorities, 01.002.1995, approved from Republic of Albania on 29.06.1995.

-DCM Nr. 493, dt. 18.09.1995 allows learning of Greek language in high schools of Dervician and Bularat.

-DCM Nr. 502, dt 05.06.1996 allows education of Greek minority in 8-year schools of Gjirokastër.
} 
Vllaho-Psilloterë and Biovizhdë with 111 people or about $0.1 \%$ of the population. Dervician villages (1267 inhabitants ${ }^{15}$ ) and Grapshi had mixed and bilingual population (Greek and Albanian).

In the area where the Greek nationality population was living (37 settlements), there were 22 schools, while in 1923 opened three new schools in villages Jergucat, Bodrishtë and Zervat.

Table 1: Education of Greek minorance in 1923

\begin{tabular}{|l|c|c|c|}
\hline Description & Schools & Pupils & Teachers \\
\hline Sub-Prefecture of Centre & 7 & 506 & 7 \\
\hline Sub- Prefecture Libohovës & 15 & 924 & 17 \\
\hline
\end{tabular}

After the liberation, in 1953, 4 family of Greek nationality settled in the village Kakoz. Since 1970, mainly through marriage, in Tepelena went inhabitants of Greek nationality from Saranda and Gjirokastra. The lower rate of population growth of Greek nationality is related to the higher education and urbanization. In the years 1985-1990, the natural increase in the district of Gjirokastra was $16 \%$, in the commune of Pogon $11 \%$, Upper Dropull $9 \%$, Lower Dropull $11 \%$, Picar $19 \%$ and Lunxhëri $16 \%$.

Greek minority was deployed in rural areas as Pogoni valley, province of Upper Dropull and Lower Dropull Rrëzë of Përmet, Biovizhdë villages and Psilloterë Vllaho of Çarçovë Commune along the Vjosa valley, on the border with Greece.

After 1990, education in communes populated by the Greek minority was accomplished in 2 kindergartens, 13 schools of 8 years system, 2 schools (in the Bularat \& Dervician), where were working 67 teachers from 169 in 1999. This fact indicates the high level the migration of teachers from area Dropulli and Pogon. Due to the great wave of migration (40-70\%) to Greece, the ethnic structure changed.

In the town of Gjirokastra, in the 8-year-school "Urani Rumbo" learn $106^{16}$ children of the Greek minority Since 1955, pedagogical high school "Pandeli Sotiri" graduated teacher of Greek for low cycle of education, and since 1993, the branch of "Greek Language and Literature " at the University "Eqrem Cabej" graduated teacher and researcher of Greek language and literature. In the area where the Greek minority is living there is a considerable development of private businesses of regional and national importance. This is affected from the proximity to the border, which allow free movement and establishment of joint businesses with Greece, road infrastructure, improved significantly in recent years, and remittances (remittances) of immigrants, a significant part of which is used for the construction sector (mainly for the stone quarries).

Table 2: Gjirokastër structure acording to the general register of population and houses of 1989

\begin{tabular}{|c|c|c|c|c|c|c|c|c|c|c|c|}
\hline \multicolumn{12}{|c|}{ In absolute values } \\
\hline \multirow[b]{2}{*}{ Description } & \multirow[b]{2}{*}{ Total } & \multirow[b]{2}{*}{ Albanian } & \multirow[b]{2}{*}{ Non- Albanian } & \multicolumn{8}{|c|}{ According to nationalities } \\
\hline & & & & Greek & Macedonian & $\begin{array}{c}\text { Montenegro } \\
\text { \& Serbs }\end{array}$ & $\begin{array}{l}\text { Romanian (vllahs), } \\
\text { Bulgarians \& Czech }\end{array}$ & Izraelians & |talians & Russian & others \\
\hline Place & 3182417 & 3117601 & 64816 & 58758 & 4697 & 100 & 782 & 73 & 53 & 36 & 317 \\
\hline Region & 155998 & 135097 & 20901 & 20420 & 14 & 4 & 418 & 13 & 4 & 0 & 28 \\
\hline Gjirokastër & 66373 & 45978 & 20395 & 19921 & 9 & 4 & 417 & 13 & 4 & 0 & 27 \\
\hline Përmet & 39775 & 39330 & 445 & 442 & 2 & 0 & 1 & 0 & 0 & 0 & 0 \\
\hline Tepelenë & 49850 & 49789 & 61 & 57 & 3 & 0 & 0 & 0 & 0 & 0 & 1 \\
\hline \multicolumn{12}{|c|}{ In percentage } \\
\hline \multirow[b]{2}{*}{ Description } & \multirow[b]{2}{*}{ Total } & \multirow[b]{2}{*}{ Albanian } & \multirow[b]{2}{*}{ Non- Albanian } & \multicolumn{8}{|c|}{ According to nationalities } \\
\hline & & & & Gree & Macedonian & $\begin{array}{c}\text { Montenegro } \\
\text { \& Serbs }\end{array}$ & $\begin{array}{l}\text { Romanian (vllahs), } \\
\text { Bulgarians \& Czech }\end{array}$ & Izraelian & |talians & Russian & others \\
\hline Place & 100 & 98 & 2 & 1.83 & 0.13 & 0.004 & 0.02 & 0.002 & 0.003 & 0.001 & 0.01 \\
\hline Region & 100 & 86.6 & 13.4 & 13.1 & 0.008 & 0.002 & 0.26 & 0.008 & 0.002 & 0 & 0.02 \\
\hline Gjirokastër & 100 & 69.3 & 30.7 & 30 & 0.01 & 0.01 & 0.6 & 0.02 & 0.01 & 0 & 0.05 \\
\hline Përmet & 100 & 98.9 & 1.1 & 1.092 & 0.005 & 0 & 0.003 & 0 & 0 & 0 & 0 \\
\hline Tepelenë & 100 & 99.9 & 0.1 & 0.092 & 0.006 & 0 & 0 & 0 & 0 & 0 & 0.002 \\
\hline
\end{tabular}

15 Mema, B., Greek Minority in Albania during the period 1920-1924, University Researches 4, Gjirokastër 2001, pg.105-111

${ }^{16}$ Zisi, R., Educational current problems of the Greek minority in districts of Gjirokastër, Delvinë, Sarandë, University Researches 6 , Gjirokastër 2002, pg. 116. 
After WWII the Greek minority was extended in Tepelena and Memaliaj towns: in October 1997, in Tepelenë were 241 citizens of Greek nationality, while in Memaliaj 155. During the period 1991-1997 the majority of citizens of Greek nationality have immigrated to Greece, even some have Greek nationality.

Table 3: Registring of Greek minority in 2001

\begin{tabular}{|c|c|c|c|c|}
\hline \multirow{2}{*}{ Description } & \multirow{2}{*}{ Total population } & \multicolumn{3}{|c|}{ Minoriteti etnik grek } \\
\cline { 3 - 5 } & 3069275 & Total & Families & Member \\
\hline Place & 112831 & 18668 & 9616 & 3.9 \\
\hline Region & 7558 & 7558 & 1733 & 4.2 \\
\hline Lower Dropull & 8525 & 8525 & 1986 & 4.4 \\
\hline Upper Dropull & 907 & 907 & 284 & 3.3 \\
\hline Pogon & 95841 & 1678 & 409 & 4.1 \\
\hline Other & \multicolumn{3}{|c}{} \\
\hline
\end{tabular}

Registration of Population and dwelling houses in 2001, 1.17\% of the population (present) of the country and $16.5 \%$ of the Region population was of Greek nationality (shown to the map ethnicity below).

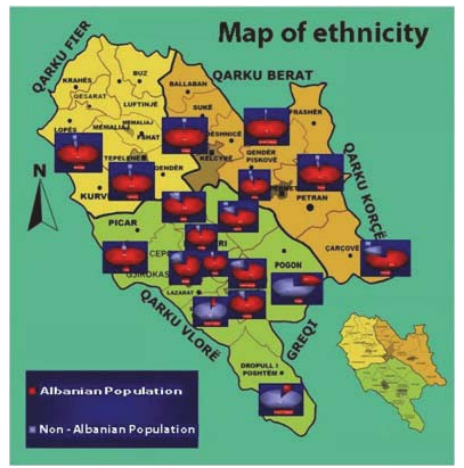

\section{Organization and Architecture of Rural Settlements}

Gjirokastra district rural areas have outstanding value from the organizational way of space and landscape, as well as the architecture and internal organization of housing and other buildings, infrastructure etc. They are the revitalising of the contribution of talented local masters (the Lunxhëria, Dangëllia, Shqeria) of neighboring territories (Kolonja builders etc.) and the Greek minority. Monumental works stand out in the field of construction, such as paths, bridges, water pipelines and taps, two-storey dwellings, objects of worship (mosques, monasteries, churches, mosques shrines etc.), Irrigation and drainage systems etc.

Key elements are spatial settlement:

- Centers,

- Residential homes,

- Streets and squares,

- Social and cultural buildings,

- Playgrounds and green spaces

Depending on the terrain and other factors, natural and human, villages are organized in different ways. In mountainous terrain, the towns have some neighbourhoods, far apart and surrounded by farmland, with particular economy and home separate or grouped. In hilly villages are grouped and organized, but in many cases, two or more neighbourhoods. In the field of relief settlements have greater density of buildings, usually a centre, concentric road network and almost the same model apartment enters, connected with internal road network and the main road, perform the function of the hotbeds of social life, constituting the core of urban settlements composition. They comprise architectural ensembles, where can be found expression of cultures, traditions and customs of the rural population (residents meet and chat around a plane tree or old oak secular tree, well, pump, source, an object of worship or the 
historic square, the assembly of men, a main street where are carried out administrative, cultural and commercial, activities etc.). There residential homes, which are higher, create the image of architectural centre, making it aesthetically vibrant, functional, social-cultural, commercial, etc.

Residential areas are located in the best lands, protected from the winds, with a lot of sun, ventilated and forested. In the villages, natural landscapes, built near the centres of green massifs, panoramic statements, rivers, lakes, reservoirs, etc.

Of great importance are centres of agricultural enterprises (cooperatives or state farms) and agricultural regions. Economic construction complexes in rural areas are livestock (buildings where cattle breed), agriculture (agricultural products stores, mechanics, etc.) And crafting-industrial (processing units of agricultural and livestock products, stone, wood, etc.). Agricultural economic character objects are placed in their vicinity, because they serve both production and population, while stables form independent unit away from residential area, in order don't damage hygiene, functionality, urban and architectural elements of the village. Slaughterhouses and poultry with over 3000 animals have been located over 500 meters away from the residential area, stables for cows, pigs, horses and poultry over $250 \mathrm{~m}$, crafting workshops over $200 \mathrm{~m}$, stables for work animals over $100 \mathrm{~m}$ etc.

Usually residence and economic areas are situated in:

- close to national road (in one side of it) and the entrance in each area is done through special roads such are: in villages of Bënçë, Turan, Dragot, Qesarat, Buz etc, of Tepelenë District; Sotirë, Llovinë, Upper Peshkëpi, Dervician and Jergucat, of Gjirokastër District; Kondas, Komarak, Sukë, Këlcyrë Village, Piskovë, Gjinkar, Petran etc, of Përmet District;

- far from the national road (in one side of it) and the entrance in each area is done through common roads such are: in villages of Communes of Upper Dropull, Zervat, Bularat etc, in Gjirokastër District and Luzat of Tepelenë District;

- very far from the national road and the connection with village is done through internal road of agriculture area in far mountanous areas: Kërrë and Kaparjel of Gjirokastra District; Mezhgoran in Tepelenë District; Limar, Malëshovë, Bubës, Toshkëz, villages of Ballaban, Dëshnicë, Sukë, Frashëri in Përmet District;

- In both sides of national roads such are villages of Lower Peshkëpi, Vllaho Goranxi, Çatistër etc, in Gjirokastra District; Mazhanj in Përmet District, Lab Martalloz, Sinanaj, Salari, Dukaj, in Tepelenë District;

- In the crossing section of national roads such are in villages of Glinë, Suhë, Labovë e Vogël etc, in Gjirokastër District; Çarçovë in Përmet District; Salari in Tepelenë District etc;

- In one side of national road and the connection is done in two points through an internal ring such are in the villages of Humelicë, Çepunë, Mashkullorë, Kordhocë, Commune of Lower Dropull, villages of Jergucat, Zervat, Bularat, Kakavie etc, in Gjirokastra District.

\section{Agricultural Cities and their Role in Rural Development}

Except Libohovë, the towns in the region lie in the relief field, where compactness is greater than in the hilly, there are more massive constructions (with rectangular blocks) and construction density is greater. The streets are straight, wide and small slope. Socio-economic development, changes in lifestyles, etc., have improved functional structure of region cities. Administrative cities (Gjirokastra, Permet and Tepelena) are old. They were created as centres of fortified residential type, and then are extended outside the fort, on the hilly slopes and in the field, becoming the economic and craft centres. During the years of communist regime, they developed rapidly, as cities with complex functions administrative, industrial, handicraft, agricultural, cultural, and educational, with the development of transport and trade and compact neighbourhood. After the Liberation of the country, one of the characteristics of urban development has been the establishing of new towns and agricultural towns, according to the studied urban planning, residential, socialcultural and economic buildings, with street and service unit of civil style. In the transformation of rural settlements into cities, in addition to economic factors, an important role have played social elements and urbanization, historical traditions and cultural centres as it is the case of Libohovë and Këlcyrë. Agricultural towns have functioned cooperatives or agricultural enterprises, SMT-etc. Apart from the agricultural sector, these cities gradually has gained crafting-industrial functions (processing of agricultural and livestock products), trade (collection, package and sell in large urban centres and processing facilities) and cultural (houses of culture, libraries, sports teams, etc.) and education (vocational secondary schools, mainly agricultural). They have contributed significantly to the emancipation and the urbanization of rural society.

After 1990, in terms of rapid and chaotic urbanization, functional structure of the city has expanded and extended 
their influence into larger areas. Urban areas of the region, has 1745 agricultural enterprises, of which 846 belong to the municipalities, mainly that of Libohovë (805 entities) and Këlcyra. Këlcyra represents the municipality with the highest utilization of arable land (60.8\%), while Municipality of Tepelenë only 16.9\%. In 1998, 55.1\% of the regional urban space was utilized agricultural area. In Gjirokastra district municipalities, agricultural lands occupied 1189 ha, 92.8\% of which were arable land (264 ha and 912 ha of Gjirokastra municipality Libohovë municipality); Përmet district municipalities, agricultural lands occupied 1165 ha, 78.5\% of which were arable land (375 ha and 790 ha Përmet municipality and Këlcyrë municipality); while in the municipalities of Tepelena agricultural lands occupied 79 ha (12 ha and 67 ha Municipality of Tepelenë Municipality of Memaliaj).

In the period 1994-2004, except Libohovë in all municipalities the number of farmers decreased. More farmers had Municipality of Libohovë : $43.2 \%$ of the farmers of urban area. Operating in urban area there are 802 entities which cultivate grains and 658 entities that grow vegetables, beans and potatoes, most of which are in municipalities Libohovë and Këlcyrë.

- Municipality Gjirokastër, in 2004 had 7800 grape plants, 120 citrus trees and produced $1.1 \mathrm{~kg} / \mathrm{person}$ vegetables and $0.2 \mathrm{~kg} /$ person potatoes.

- Municipality Përmet, in 2004 had over 2000 grape plants.

- Municipality Tepelenë, in 2004 had over 2600 olive trees and produced $7.4 \mathrm{~kg} /$ person vegetables.

- Municipality Libohovë,in 2004 had over 6000 fruit trees, 700 olive trees and 3000 grape plants. In 2004 this Municipality produced $178.7 \mathrm{~kg} / \mathrm{person}$ grains, $203 \mathrm{~kg} /$ person vegetables, $6.8 \mathrm{~kg} / \mathrm{person}$ beans and 33.8 $\mathrm{kg} / \mathrm{person}$ potatoes.

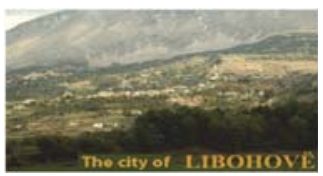

- Municipality Këlcyrë, in 2004 produced $73.6 \mathrm{~kg} /$ person grains, $61.3 \mathrm{~kg} /$ person vegetables, $4.6 \mathrm{~kg} / \mathrm{persons}$ beans and $24.2 \mathrm{~kg} /$ person potatoes, while the producing of industrial plants focused (mainly sunflowers) and continued like this till 1999.

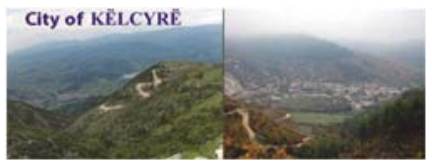

- Municipality Memaliaj, in 2004, produced $3.6 \mathrm{~kg} /$ person vegetables.

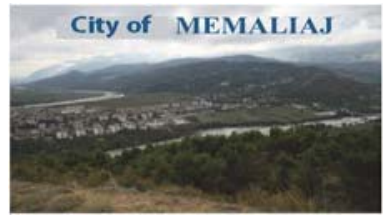

\section{Role of Administrative Structure in 1992 in Reorganising the Network of Rural Residences}

\subsection{Role of Commune's centres}

Administrative-Territorial Organizing expresses features of historical evolution and social-economic development of the region. After the Decision of Council of Ministers Nr. 269, dt. 25.06.1992 "For the administrative- territorial division of Albanian Republic", it was done a reorganising of the network of rural residences in Gjirokastër region. Based on the Law 
Nr. 7605, dt. 15.09.1992 "for the division of territory in Municipality and Communes"17, it was established a new administrative-territorial division for each village

In Gjirokastër district, were established Comunes of Antigone, Cepo, Lower Dropull, Upper Dropull, Lazarat, Lunxhëri, Odrie, Picar, Pogon, Qendër Libohovë and Zagorie; in Përmet District, were established Communes of Ballaban, Çarçovë, Dëshnicë, Frashër, Petran, Piskovë Center and Sukë; in Tepelenë District, were established Coomunes of Tepelenë Centre, Memaliaj Village, Buz, Luftinjë, Krahës, Qesarat, Lopës and Kurvelesh administrativeterritorial division.

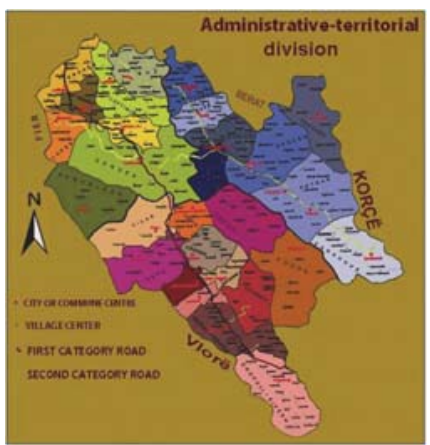

\section{7. "Wild" Construction in Rural Residencies and their Role in Consuming the Agricultural Areas}

\subsection{Regulatory policies about rural areas before 1990.}

Until 1990, social-economic factor was determining in a limiting way the implementation of the regulatory policies about rural settlements. During the period mentioned above the system aimed at limiting the occupation of agricultural land and increasing population density in the rural area. It was aimed to turn the village like the city, raising palaces changing lifestyles, developing, besides agriculture, and other economic activities.

In 1960, the Ministry of Agriculture and Cadastre branch approved guidelines which disciplined construction in the countryside, such as apartments, as well as social and economic facilities and cultural activities. In 1961 came out the decree and instruction of the Cabinet of Ministers "On saving the fertile soil from construction and other works", and in 1978 came out the decree and the relevant regulation "On the drafting, approval and implementation of the regulatory plans of cities and villages". Therefore, it changed the way of conception and design of residential houses in the village. In order that these constructions were not wasteful and damaging the unity of blocks of land belonging to agricultural cooperatives and were established the executive committees of special commissions for construction in the village. They were aimed at preserving and saving as much arable land area from the construction and various works by defining unproductive land designated for construction. The size of the expansion of the residential centre was calculated from net population density/ha. This density should be $\geq 90$ inhabitants / ha and $\leq 150$ inhabitants / ha. Also by this Ministry were issued instructions about the main roads in a residential centre, which should not be more than two. In subsequent periods, the booklet "Planning urban agricultural centres" served for setting residential centres, production areas and also for the design of rural regulatory plans of residencies. This was followed by turning of a portion of farmland (especially fields and orchards) in non-agricultural areas (for roads, canals, residential, economic etc.).

\subsection{The period after 1990}

After 1990 have not been implemented proper policies for the development of rural areas, but there was a spontaneous stretch of individual houses of 2-3 floors in rural area of the county. At Urban Directorate at Regional Council there are a lot of requests from municipalities for urban studies, construction and individual (family) using for housing, combined with facilities for small crafts or manufacturing enterprises. Rural areas tend to be stretched to flat areas near the national 
roads, as well as to larger settlements. The request for the extension of the settlements has Lunxhëri, Lower Dropull, Antigone, Cepo, Petran, Piskovë Hub, Hub Tepelenë, Memaliaj Village Communes etc.

Table 4: Constructions built withouth permission on agricultural lands in Gjirokastër Region

\begin{tabular}{|c|c|c|c|c|c|c|}
\hline \multicolumn{4}{|c|}{ In Total: } & \multicolumn{2}{c|}{ Constructed } & \multicolumn{2}{c|}{ Flat area } \\
\hline Unit & $\mathrm{Nr}$ & $\mathrm{Ha}$ & $\mathrm{Nr}$ & $\mathrm{Ha}$ & $\mathrm{Nr}$ & $\mathrm{Ha}$ \\
\hline Region & 213 & 11 & 200 & 7 & 13 & 4 \\
\hline Gjirokastër & 105 & 9 & 92 & 5 & 13 & 4 \\
\hline Përmet & 34 & 0.5 & 34 & 1 & - & - \\
\hline Tepelenë & 74 & 1.3 & 74 & 1 & - & - \\
\hline
\end{tabular}

During this period were approved many building permits for objects of various kinds. Social-cultural facilities, health and infrastructure are financed mainly by state investors, while most of the residential buildings, hotels, restaurants, industrial and other activities have been financed by private investors and companies.

\section{Conclusions}

Agricultural function is implemented mainly in hilly and field terrain. Livestock function has settlements in high hilly and mountainous relief, with considerable pasture area (pastures, meadows and moat). In order to identify the villages and communes with livestock function is used indicator of pasture area. Agro-tourism function is evident mainly in settlements with remarkable agricultural traditions (where are implemented agricultural practices attractive to tourists), but also in places with tradition in the management of forests, water, etc. Agro-industrial function is dominant in settlements near cities, where are developed handicrafts and processing industry of agricultural products and livestock. Villages mentioned above, enjoyed the status of the administrative centre were also territorial centres of village systems locality, or agricultural enterprises- cooperative. Gjirokastra district rural areas have outstanding value from the organizational way of space and landscape, as well as the architecture and internal organization of housing and other buildings, infrastructure etc. After 1990, in terms of rapid and chaotic urbanization, functional structure of the city has expanded and extended their influence into larger areas. After 1990 have not been implemented proper policies for the development of rural areas.

Ethnic composition is homogeneous in Gjirokastra district. The ethnic Greek minority and cultural communities Vlachos and Roma, with values of material and spiritual culture, have enriched the cultural mosaic of the region. Especially it is evident in the spatial organization of dwelling houses, type of dwelling houses and architecture, traditions, agriculture, livestock and handicraft sector etc.

Cohabitation of the Albanian and Greek population, especially in the rural area, have approximate customs and traditions, communication and behaviour, building style furnishing of flats, etc., creating an original model of the rural community, which can serve as geo spatial nucleus of a regional cross-border dimensions, where citizens of both countries (Albania and Greece) are working for sustainable rural development.

\section{References}

Constituency of Socialist Republic of Albania (1976), introduced de jure minorities, Paris Convent for a new Europe (1990).

Constitution Dispositions of 1991, improve the status of minorities.

DCM Nr. 493, dt. 18.09.1995 allows learning of Greek language in high schools of Dervician and Bularat.

DCM Nr. 502, dt 05.06.1996 allows education of Greek minority in 8-year schools of Gjirokastër.

Declaration of Union of Nations, 02.10.1921.

EU Convent - with the framework to protect national minorities, 01.002.1995, approved from Republic of Albania on 29.06.1995.

International \& National Legislation for protection of national minorities in Gjirokastër Region.

Law of year 1993 "About the rights and principal freedoms of human beings", DCM Nr. 396, dt 22.08.1994 allows learning of native language even in the areas which are not inhabited from minority population.

Mema, B., Greek Minority in Albania during the period 1920-1924, University Researches 4, Gjirokastër 2001

National Convents for civil and political rights (1966).

Office of Assets Registration in three Districts of Gjirokastër Region.

Official Note Book 1992, Tiranë 1995.

Official Notebook 2, 21 March 1958. 
Official Notebook nr 10, 25 December 1965.

Official Notebook nr 14, 15 September 1952.

Official Notebook nr 14, 25 September 1954.

Official Notebook nr 18, 30 December 1955.

Official Notebook nr 25, Year VI, 6 April 1949.

Official Notebook nr 6, 10 May 1967.

Official Notebook nr 9, 10 August 1956.

Official Notebook, 19 May 1934.

Official Notebook, 28 December 1940.

Official Notebook, 30 March 1950.

Official Notebook, Year of XVII, 17 June1938.

Universal Declaration of Human Rights (1948)

Zisi, R., Educational current problems of the Greek minority in districts of Gjirokastër, Delvinë, Sarandë, University Researches 6 , Gjirokastër 2002. 